\title{
ANALISIS PENGARUH MODEL PEMBELAJARAN KOOPERATIF TIPE MAKE A MATCH TERHADAP HASIL BELAJAR SISWA PADA PEMBELAJARAN IPS SD
}

\author{
Ika Sholihatul Maulida, Dewi Widiana Rahayu, \\ Muhammad Thamrin Hidayat, Suharmono Kasiyun \\ Surel : ikasholihatulmaulida98@gmail.com
}

\begin{abstract}
The purpose of this research was to analyze the effect of before and after the applied of make a match in improving the learning outcomes of social science in elementary school. The study used a meta analysis method. This research begins by formulating the topic to be examined, make a statement of the problem, and at the final stage is to search relevant articles to data collections. The data is obtained by searching online journals through google scholar with search keywords "make a match", "learning outcomes", and "learning social science in elementary school". From the research results obtained as many as 35 articles but only 10 articles are relevant for use. The data obtained is processed again using quantitative method. Based on the analysis of student learning outcomes in elementary social studies learning can be increased by an average value before the model is applied to make a match of 45 can increase by 10 to 55 .
\end{abstract}

Keywords: Make a Match, Learning Outcomes, Learning Social Science in Elementary School.

\begin{abstract}
ABSTRAK
Penelitian ini bertujuan untuk menganalisis pengaruh sebelum dan sesudah diterapkan model Make A Match untuk meningkatkan hasil belajar IPS SD. Metode yang digunakan dalam penelitian ini adalah metode meta analisis. Penelitin ini diawali dengan merumuskan topik yang akan diteliti, membuat rumusan masalah, dan pada tahap akhir yaitu menelusuri artikel yang relevan untuk pengumpulan data. Data tersebut diperoleh dengan cara menelusuri jurnal online melalui google scholar dengan kata kunci pencarian "Make A Match", "hasil belajar", dan "pembelajaran IPS SD". Dari hasil penelusuran diperoleh sebanyak 35 artikel tetapi yang relevan untuk digunakan hanya 10 artikel. Data yang diperoleh diolah kembali menggunakan metode kuantitatif. Berdasarkan hasil analisis hasil belajar siswa pada pembelajaran IPS SD dapat meningkat dengan nilai rata-rata sebelum diterapkan model make a match sebesar 45 dapat meningkat sebesar 10 menjadi 55.
\end{abstract}

Kata Kunci: Make a Match, Hasil Belajar, Pembelajaran IPS SD.

\section{PENDAHULUAN}

Pembelajaran

merupakan

suatu proses komunikasi dua arah, mengajar dilakukan oleh guru sebagai pihak pendidik, sedangkan belajar dilakukan oleh peserta didik (Sagala,
2006:16). Guru dan peserta didik merupakan subjek yang paling berpengaruh pada proses pembelajaran. Dimana guru dituntut untuk mengeluarkan segala kemampuan yang dimilikinya untuk 
diberikan kepada peserta didik pada saat proses pembelajaran berlangsung. Agar peserta didik dapat mencapai hasil belajar yang maksimal seorang guru harus mampu menyesuaikan antara bahan ajar dengan model pembelajaran yang cocok. Untuk mencapai tujuan pembelajaran yang diharapkan perlu melibatkan komponen yang satu dengan yang lainnya, komponen tersebut meliputi siswa, guru, metode, lingkungan, media pembelajaran, sarana dan prasarana. Agar tujuan pembelajaran bisa tercapai maka guru harus mampu mengkoordinasikan komponen-komponen pembelajaran dengan baik, sehingga terjadi interaksi aktif antara siswa yang satu dengan yang lain dan guru dengan siswa. (Suprihatiningrum, 2017:77).

Seorang guru profesional dituntut untuk dapat menampilkan keahliannya sebagai guru didepan kelas. Menggunakan bermacammacam model pembelajaran yang bervariasi yang dapat menarik minat belajar siswa merupakan komponen yang harus dikuasai oleh guru. Hal ini sejalan dengan pendapat Mulyasa (2003:101) yang menyatakan bahwa proses pembelajaran dikatakan berhasil dan berkualitas apabila seluruh peserta didik terlibat secara aktif, baik fisik, sosial maupun mental.

Lemahnya pelaksanaan proses pembelajaran yang diterapakn oleh guru disekolah menjadi penyebab salah satu masalah yang dihadapi dalam dunia pendidikan. Pelaksanaan pembelajaran yang terjadi selama ini kurang mengembangkan kemampuan berpikir siswa. Pelaksanaan pembelajaran yang berlangsung didalam kelas hanya diarahkan pada kemampuan siswa untuk menghafal informasi tanpa dituntut untuk memahami informasi yang diperoleh untuk menghubungkannya dengan situasi dalam kehidupan sehari-hari (Susanto, 2013:165). Proses pembelajaran yang demikian tidak akan mendorong siswa untuk mengembangkan potensinya, kurang menumbuhkan aktivitas siswa serta daya cipta (kreativitas) dalam proses pembelajaran. Pelaksanaan model pembelajaran yang monoton akan mengurangi motivasi siswa untuk belajar. Hal ini disebabkan karena siswa merasa jenuh dengan model pembelajaran yang sama secara terus menerus.

Kondisi seperti ini juga terjadi pada proses pembelajaran IPS di sd, yang memperlihatkan bahwa selama ini proses pembelajaran IPS di sekolah dasar cenderung lebih banyak mengembangkan kemampuan menghafal materi pelajaran, siswa belum dibiasakan untuk memahami informasi yang ada dan menghubungkannya dengan kehidupan sehari-hari. Pembelajaran IPS di sd masih berpusat pada guru dan siswa belum dijadikan subjek belajar. Pembelajaran cenderung lebih banyak menempatkan siswa pada aktivitas mendengar, mencatat, atau menjawab pertanyaan dari guru. Tanpa melibatkan interaksi dan kerjasama antara siswa yang satu dengan yang lain. Pada kegiatan 

pembelajaran yang demikian dapat menjadikan proses pembelajaran yang membosnkan dan monoton. Sehingga siswa menjadi pasif dan malas belajar karena sistem pembelajarannya tanpa menggunakan variasi yang dapat menarik minat siswa. Pelaksanaan pembelajaran belum sepenuhnya dilakukan secara aktif dan kreatif oleh para guru dalam melibatkan siswa saat belajar. Keberhasilan proses kegiatan belajar pada mata pelajaran IPS sd dapat dilihat dari pemahaman, penguasaan materi yang diserap oleh siswa. Tujuan pembelajaran IPS akan tercapai apabila siswa menguasai materi pokok yang telah dipelajari. Penguasaan materi siswa dapat dilihat melalui hasil belajar siswa yang diperoleh setelah mengikuti kegiatan pembelajaran. Maka dari itu guru perlu melibatkan siswa sebagai unsur utama dalam ketuntasan mengajar. Ketuntasan mengajar dikatakan berhasil apabila tingkat penguasaan siswa pada materi yang sudah mencapai standar Kriteria Ketuntasan Minimum (KKM) yang ditetapkan oleh pihak sekolah.

Untuk mengatasi masalah tersebut maka dalam proses pembelajaran perlu dilakukan inovasi, salah satunya dengan menggunakan model-model pembelajaran yang aktif, kreatif dan inovatif. Model pembelajaran kooperatif tipe Make A Match merupakan salah satu model pembelajaran yang bisa digunakan untuk membuat siswa belajar lebih aktif dan menyenangkan, mengembangkan sikap kerjasama dan dapat meningkatkan hasil belajar. Dimana salah satu keunggulan metode Make A Match yaitu siswa mencari pasangan antara kartu soal dan kartu jawaban yang sesuai mengenai suatu konsep atau topik yang dipelajari dalam suasana yang menyenangkan, dan siswa dapat belajar sambil bermain. Sehingga model ini memiliki hubungan erat dengan karakteristik siswa sd yaitu siswa dapat belajar sambil bermain. Keaktifan siswa untuk bergerak mencari pasangan dengan kartu yang sesuai dengan jawaban atau pertanyaan dalam kartu merupakan salah satu faktor pendukung dalam melaksanakan model Make A Match. (Shoimin, 2014:98).

Kelebihan model pembelajaran kooperatif tipe Make A Match menurut Huda (2013:253) yaitu: dapat meningkatkan aktivitas belajar siswa, baik secara kognitif maupun fisik, karena ada unsur permainan, model penmbelajaran ini menyenangkan, meningkatkan pemahaman siswa terhadap materi yang dipelajari dan dapat meningkatkan motivasi belajar siswa, efektif sebagai sarana melatih keberanian siswa untuk tampil presentasi, efektif melatih kedisiplinan siswa menghargai waktu untuk belajar.

Berdasarkan uraian tersebut, maka penelitian lebih fokus pada "Apakah terdapat pengaruh sebelum dan sesudah penggunaan model pembelajaran Make A Match terhadap hasil belajar siswa pada mata pelajaran IPS SD?"

\section{METODE PENELITIAN}

Metode yang digunakan dalam penelitian ini yaitu metode meta analisis. Metode meta analisis merupakan salah satu metode yang digunakan untuk merangkum temuan dua penelitian atau lebih dengan tujuan untuk meninjau, menggabungkan, serta meringkas penelitian sebelumnya. Metode meta analisis tidak bersifat subjektif dibandingkan dengan metode lainnya, 
melainkan fokus pada data. Pengumpulan data dilakukan dengan menelusuri artikel pada jurnal online yang relevan dengan topik yang diteliti. Dari hasil penelusuran pada google scholar diperoleh 35 artikel kemudian diambil 10 artikel yang telah diterbitkan pada jurnal online dengan ketentuan yang terdapat hasil data sebelum dan sesudah dilakukan tindakan dalam bentuk angka untuk kepentingan perhitungan yang bersifat kuantitatif. Adapun langkah-langkah yang harus dilakukan untuk menganalisis data dalam penelitian ini yaitu menganalisis data rata-rata hasil belajar sebelum dan sesudah diterapkan model pembelajaran Make A Match yang diperoleh dari penelusuran jurnal online melalui google scholar dengan kata kunci model Make A Match, hasil belajar siswa dan pembelajaran IPS sd.

\section{HASIL PENELITIAN DAN PEMBAHASAN}

Berikut adalah hasil penelitian sebelumnya yang digunakan ke dalam penelitian meta analisis ini:

- Pengaruh Model Pembelajaran Kooperatif Teknik Mencari Pasangan (Make A Match) Terhadap Hasil Belajar IPS Siswa Kelas IV SD Oleh Ni Pt. Dayantari, Ndara Tanggu Renda, Ni Ngh. Madri Antari.

- Pengaruh Model Pembelajaran Kooperatif Tipe Make A Match Berbantuan Media Audio Visual Terhadap Hasil Belajar IPS Sekolah Dasar Oleh Ketut Gading, Kadek Dian Kharisma.

- Pengaruh Make A Match Berbantuan Media Kartu Gambar Terhadap Hasil Belajar IPS SD Oleh G. A. Ary Anggarawati, MG. Rini Kristiantari, G. A. Agung Sri Asri.
- Penerapan Model Make A Match Dalam Upaya Peningkatan Hasil Belajar IPS Siswa SD Oleh Epri Nuraini Rusminawati Dan Nani Mediatati.

- Pengaruh Model Pembelajaran Make A Match Terhadap Hasil Belajar IPS Siswa Kelas V SD Oleh Nym. Masa, Nym. Murda, Luh Pt. Putrini Mahadewi.

- Penerapan Model Pembelajaran Kooperatif Tipe Make A Match Berbantuan Kartu Bergambar Untuk Meningkatkan Hasil Belajar Siswa Oleh Dhesta Hazilla Aliputri.

- Pengaruh Penggunaan Make A Match Pada IPS Terhadap Hasil Belajar Siswa Kelas V SDN 41 Sungai Raya Oleh Bonifasius Arief Gunawan, Suhardi Marli, Hery Kresnady.

- Pengaruh Model Pembelajaran Kooperatif Tipe Make A Match Dengan Media Kartu Bergambar Tema Cita Citaku Terhadap Hasil Belajar Siswa Kelas IV SDN Patrang 01 Jember Oleh Syeni Ayu Kirnanti.

- Penerapan Model Pembelajaran Kooperatif Tipe Make A Match Untuk Meningkatkan Hasil Belajar Siswa Pada Mata Pelajaran IPS Siswa Kelas IV MIN Tunggangri Kalidawir Tulungagung Oleh Lutviana Devi.

- Penerapan Model Pembelajaran Make A Match Untuk Meningkatkan Hasil Belajar Siswa Pada Tema Daerah Tempat Tinggalku Dikelas IV MI Lamgugob Kota Banda Aceh Oleh Nurul Fitria. 
Ika Sholihatul Maulida : Pengaruh Model Pembelajaran ...

Tabel 1. Hasil Analisis Model Pembelajaran Make A Match

\begin{tabular}{|c|c|c|c|c|c|}
\hline \multirow{2}{*}{ No } & \multirow{2}{*}{ Topik Penelitian } & \multirow{2}{*}{ Peneliti } & \multicolumn{3}{|c|}{ Peningkatan Hasil Belajar } \\
\hline & & & Sebelum & Sesudah & Gain \\
\hline 1 & $\begin{array}{l}\text { Model pembelajaran make } \\
\text { a match, hasil belajar IPS } \\
\text { siswa kelas IV }\end{array}$ & $\begin{array}{l}\text { Ni Pt. Dayantri } \\
\text { Ndara Tanggu } \\
\text { Renda, Ni Ngh } \\
\text { Madri Antari }\end{array}$ & 18,81 & 23,46 & 4,65 \\
\hline 2 & $\begin{array}{l}\text { Model pembelajaran make } \\
\text { a match, media audio } \\
\text { visual, hasil belajar IPS SD }\end{array}$ & $\begin{array}{lr}\text { Ketut } & \text { Gading, } \\
\text { Kadek } & \text { Dian } \\
\text { Kharisma. } & \\
\end{array}$ & 15,00 & 23,28 & 8,28 \\
\hline 3 & $\begin{array}{l}\text { Model pembelajaran make } \\
\text { a match, media kartu } \\
\text { gambar, hasil belajar IPS } \\
\text { SD. }\end{array}$ & $\begin{array}{l}\text { G.A.Ary } \\
\text { Anggarawati, } \\
\text { MG.Rini } \\
\text { Kristiantari, } \\
\text { G.A.Agung Sri } \\
\text { Asri. }\end{array}$ & 0,33 & 0,49 & 0,16 \\
\hline 4 & $\begin{array}{l}\text { Model pembelajaran make } \\
\text { a match, hasil belajar IPS } \\
\text { SD. }\end{array}$ & $\begin{array}{l}\text { Epri Nuraini } \\
\text { Rusminawati, } \\
\text { Nani Mediatati. }\end{array}$ & 73 & 81 & 8 \\
\hline 5 & $\begin{array}{l}\text { Model pembelajaran make } \\
\text { a match, hasil belajar IPS } \\
\text { SD. }\end{array}$ & $\begin{array}{l}\text { Nym.Masa, Nym } \\
\text { Murda, Luh Pt. } \\
\text { Putrini } \\
\text { Mahadewi. }\end{array}$ & 18,25 & 24 & 5,75 \\
\hline 6 & $\begin{array}{l}\text { Model Pembelajaran make } \\
\text { a match, media kartu } \\
\text { bergambar, hasil belajar } \\
\text { IPS SD }\end{array}$ & $\begin{array}{l}\text { Dhesta } \text { Hazilla } \\
\text { Aliputri. }\end{array}$ & 64,9 & 80,3 & 15,4 \\
\hline 7 & $\begin{array}{l}\text { Model pembelajaran make } \\
\text { a match, hasil belajar IPS } \\
\text { SD kelas V }\end{array}$ & $\begin{array}{l}\text { Bonifasius Arief } \\
\text { Gunawan, } \\
\text { Suhardi Marli, } \\
\text { Hery Kresnady. }\end{array}$ & 60,10 & 71,75 & 11,65 \\
\hline 8 & $\begin{array}{l}\text { Model pembelajaran make } \\
\text { a match, media kartu } \\
\text { bergambar, hasil belajar } \\
\text { IPS SD kelasIV. }\end{array}$ & $\begin{array}{ll}\text { Syeni } & \text { Ayu } \\
\text { Kirnanti. } & \end{array}$ & 70,53 & 81,41 & 10,88 \\
\hline 9 & $\begin{array}{l}\text { Model pembelajaran make } \\
\text { a match, hasil belajar IPS } \\
\text { SD kelas IV. }\end{array}$ & Lutviana Devi & 65,4 & 91,72 & 26,32 \\
\hline 10 & $\begin{array}{l}\text { Model pembelajaran make } \\
\text { a match, hasil belajar IPS } \\
\text { siswa kelas IV }\end{array}$ & Nurul Fitria & 61,76 & 73,52 & 11,76 \\
\hline \multicolumn{3}{|c|}{ Model Pembelajaran Make A Match } & 45 & 55 & 10 \\
\hline
\end{tabular}

Pada tahap ini dilakukan penggabungan dari 10 sampel artikel yang akan dijadikan dasar dalam artikel ini. Data yang disajikan pada Tabel 1 meliputi rata-rata sebelum dan sesudah penggunaan model Make
A Match dan gain pada setiap penelitian. Berdasarkan hasil analisis pada tabel 1 bahwa hasil belajar siswa dapat meningkat setelah diterapkan model pembelajaran Make A Match, hal ini dapat dilihat dari hasil rata-rata 
sebelum diterapkan model Make A Match dan sesudah diterapkan model Make A Match. Nilai rata-rata sebelum diterapkan model Make A Match sebesar 45 dan dapat meningkat menjadi 55.

Tabel 2. Paired Samples Statistics

\begin{tabular}{lc|c|c|c|c}
\hline \multicolumn{5}{c}{ Paired Samples Statistics } \\
\hline & & Mean & $\mathrm{N}$ & Std. deviation & Std. Error Mean \\
\hline Pair 1 & sebelum & 44.8080 & 10 & 27.99480 & 8.85273 \\
& sesudah & 55.0930 & 10 & 33.19751 & 10.49797 \\
\hline
\end{tabular}

Pada tabel 2 Paired Samples Statistics menunjukkan bahwa ratarata hasil belajar sebelum dan sesudah menggunakan model pembelajaran Make A Match dapat meningkat dengan rata-rata 45 menjadi 55.

Tabel 3. Paired Samples Correlations

\begin{tabular}{ll|c|c|c}
\hline \multicolumn{5}{c}{ Paired Samples Correlations } \\
\hline & $\mathrm{N}$ & Correlations & Sig. \\
\hline Pair 1 & sebelum \& sesudah & $\mathbf{1 0}$ & .988 & .000 \\
\hline
\end{tabular}

Berdasarkan tabel 3 setelah dilakukan penilaian correlations menggunakan SPSS 25 for windows, menunjukkan adanya korelasi antara dua variabel yaitu pengaruh penggunaan model Make A Match dan hasil belajar IPS.

Tabel 4. Paired Samples Test

\begin{tabular}{|c|c|c|c|c|c|c|c|c|}
\hline \multirow[b]{4}{*}{$\begin{array}{c}\text { Pair 1 } \\
\text { sebelum - } \\
\text { sesudah }\end{array}$} & \multicolumn{8}{|c|}{ Paired Differences } \\
\hline & & & & \multicolumn{2}{|c|}{$\begin{array}{l}95 \% \text { confidence interval of } \\
\text { the difference }\end{array}$} & \multirow[b]{2}{*}{$\mathrm{t}$} & \multirow[b]{2}{*}{$\mathrm{df}$} & \multirow[b]{2}{*}{$\begin{array}{l}\text { Sig (2- } \\
\text { tailed) }\end{array}$} \\
\hline & Mean & $\begin{array}{l}\text { Std.deviati } \\
\text { on }\end{array}$ & $\begin{array}{c}\text { Std.error } \\
\text { mean }\end{array}$ & Lower & Upper & & & \\
\hline & $\begin{array}{c}-1 . \\
028 \mathrm{E} 1\end{array}$ & 7.08483 & 2.24042 & -15.35318 & -5.21682 & -4591 & 9 & .001 \\
\hline
\end{tabular}


Berdasarkan hasil analisis uji hipotesis pada tabel 4 Paired Samples Test yang menyatakan bahwa $\mathrm{H}_{0}=$ tidak ada pengaruh model pembelajaran Make A Match terhadap hasil belajar siswa pada pembelajaran IPS SD dan $\mathrm{H}_{1}$ terdapat pengaruh model pembelajaran Make A Match terhadap hasil belajar siswa pada pembelajaran IPS SD. Menerima $\mathrm{H}_{0}$ apabila nilai Sig.> 0,05 dan menolak $\mathrm{H}_{0}$ apabila nilai Sig. $<0,05$. Pada tabel 4 menunjukkan bahwa menolak $\mathrm{H}_{0}$ karena nilai Sig.0.001 < 0.05. Jadi dapat disimpulkan bahwa model pembelajaran Make A Match dapat memberikan pengaruh terhadap hasil belajar siswa pada pembelajaran IPS SD.

\section{Pembahasan}

Berdasarkan analisis dari 10 sampel penelitian diatas, secara umum diperoleh beberapa data bahwa dengan menggunakan model pembelajaran Make A Match dapat memberikan pengaruh yang positif pada hasil belajar siswa pada pembelajaran IPS SD. Hasil pada tabel 1 menunjukkan masing-masing penelitian yang telah dilakukan sebelumnya menunjukkan peningkatan rata-rata hasil belajar sesudah pemberian model Make A Match dengan gain paling rendah sebesar 0,16 sampai tertinggi sebesar 26, dengan rata-rata akhir sebesar 10.

Sedangkan jika dilihat dari rata-rata hasil belajar sebelum dan sesudah diterapkan model Make A Match, pada tabel 2 menunjukkan bahwa rata-rata hasil belajar sebelum sesudah diterapkan model Make A Match mengalami peningkatan. Sebelum diterapkannya model pembelajaran Make A Match ratarata hasil belajar siswa dari data 10 sampel artikel sebesar 44.8080, sedangkan jumlah rata-rata hasil belajar sesudah diterapkan model pembelajaran Make A Match sebesar 55.0930 .

Hubungan antara dua variabel pada tabel 3 juga menunjukkan correlation dengan nilai sebesar 0.98 dengan sig sebesar 0.000. hal ini menunjukkan bahwa korelasi antara dua rata-rata sebelum dan sesudah diterapkan model pembelajaran dengan Make A Match adalah kuat dan signifikan.

Dari hasil analisis diatas dapat disimpulkan bahwa model pembelajaran Make A Match dapat meningkatkan hasil belajar siswa pada pembelajaran IPS SD. Pada tabel 1, terdapat 10 sampel penelitian yang telah diteliti sebelumnya dan memiliki peningkatan hasil akhir yang berbeda, meskipun setiap penelitian menunjukkan peningkatan antara keadaan sebelum dan sesudah diterapkan model pembelajaran Make A Match. Hal tersebut dikarenakan kondisi antara yang berbeda antara siswa yang satu dengan yang lainnya.

Disamping itu ada beberapa faktor yang dapat mempengaruhi kondisi siswa pada saat pembelajaran. Misalnya faktor dari dalam, saat mengikuti pembelajaran kondisi siswa tidak stabil atau 
kondisi kesehatan siswa sedang tidak baik. Sehingga siswa tidak bisa menerima pembelajaran dengan baik yang dapat mempengaruhi hasil belajar siswa menjadi tidak maksimal. Faktor dari luar yang dapat mempengaruhi siswa misalnya dari lingkungan sekolah, kondisi sekolah, pada proses pembelajaran guru belum menggunakan model pembelajaran yang menyenangkan sehingga siswa merasa bosan, jenuh dan tidak mendengarkan apa yang disampaikan oleh guru, dan faktorfaktor lain yang dapat menimbulkan kurangnya minat siswa untuk belajar dan konsentrasi belajar siswa.

\section{SIMPULAN}

Dari hasil penelitian dan disimpulkan bahwa hasil akhir dari penelitian ini yaitu dengan diterapkannya model pembelajaran Make A Match dapat memberikan pengaruh terhadap hasil belajar siswa pada pembelajaran IPS SD. Hal ini dapat ditinjau dari data setelah diterapkan model Make A Match, hasil belajar siswa tergolong tinggi dengan hasil rata-rata dari 10 sampel berjumlah 55 dibandingkan dengan hasil rata-rata sebelumnya yang hanya berjumlah 40. Dari data tersebut terdapat kenaikan yang signifikan yaitu sebesar 10. Artinya hasil belajar siswa pada pembelajaran IPS SD dapat

\section{Kelas IV MIN Tunggangri Kalidawir}

Tulungagung. Skripsi, IAIN Tulungagung. meningkat setelah diterapkan model pembelajaran Make A Match.

\section{DAFTAR RUJUKAN}

Aliputri, Dhesta Hazilla. 2018. Penerapan Model Pembelajaran Kooperatif Tipe Make A Match Berbantuan Kartu Bergambar Untuk Meningkatkan Hasil Belajar Siswa. PGSD Universitas Kristen Satya Wacana. Jurnal Bidang Pendidikan Dasar (JBPD), Vol.2 No.1A April 2018.

Anggarawati, G. A. Ary., MG. Rini Kristiantari \& G. A. Agung Sri Asri. 2014. Pengaruh Make A Match Berbantuan Media Kartu Gambar Terhadap Hasil Belajar IPS SD. Jurnal Mimbar PGSD Universitas Pendidikan Ganesha Jurusan PGSD Vol: 2 No: 1 Tahun 2014.

Dayantri, Ni Pt., Ndara Tanggu Rendra \& Ni Ngh. Madri Antari. (2013). Pengaruh Model Pembelajaran Kooperatif Teknik Mencari Pasangan (Make A Match) Terhadap Hasil Belajar IPS Siswa Kelas IV SD. Universitas Pendidikan Ganesha Singaraja. Jurnal Undiksha: Vol 1 No 12013.

Devi, Lutviana. 2014. Penerapan Model Pembelajaran Kooperatif Tipe Make A Match Untuk Meningkatkan Hasil Belajar Siswa Pada Mata Pelajaran IPS Siswa

Gading, Ketut \& Kadek Dian Kharisma. 2017. Pengaruh Model Pembelajaran Kooperatif 
Ika Sholihatul Maulida : Pengaruh Model Pembelajaran ...

Tipe Make A Match Berbantuan

Media Audio Visual Terhadap

Hasil Belajar IPS Sekolah

Dasar. Universitas Pendidikan

Ganesha

Indonesia.

International Journal of

Elementary Education. Vol.1 (2)

pp.153-160.

Gunawan, Bonifasius Arief., Suhardi

Marli \& Hery Kresnady. 2019.

Pengaruh Penggunaan Make A

Match Pada IPS Terhadap Hasil

Belajar Siswa Kelas V SDN 41

Sungai Raya. FKIP, Untan

Pontianak. Jurnal Pendidikan

dan Pembelajaran Khatulistiwa

Vol: 8 No: 12019.

Huda, Miftahul. 2013. Model-Model

Pengajaran dan Pembelajaran.

Yogyakarta: Pustaka Pelajar.

Kirnanti, Syeni Ayu. 2018. Pengaruh

Model Pembelajaran Kooperatif

Tipe Make A Match Dengan

Media Kartu Bergambar Tema

Cita Citaku Terhadap Hasil

Belajar Siswa Kelas IV SDN

Patrang 01 Jember. Skripsi.

FKIP, Universitas Jember.

Masa, Nym., Nym Murda \& Luh Pt.

Putrini Mahadewi. 2017.

Pengaruh Model Pembelajaran

Make A Match Terhadap Hasil

Belajar IPS Siswa Kelas V SD.

e. Journal PGSD Universitas

Pendidikan Ganesha Mimbar

PGSD Vol: 5 No: 2 Tahun:

2017.
Nurul, Fitria. 2019. Penerapan Model Pembelajaran Make A Match Untuk Meningkatkan Hasil Belajar Siswa Pada Tema Daerah Tempat Tinggalku Dikelas IV MI Lamgugob Kota Banda Aceh. Skripsi. Fakultas Tarbiyah dan Keguruan (FTK), Universitas Islam Negeri ArRanairy Darussalam Banda Aceh.

Rusminawati, Epri Nuraini \& Nani Mediatati. 2017. Penerapan Model Make A Match Dalam Upaya Peningkatan Hasil Belajar IPS Siswa SD. Universitas Kristen Satya Wacana, Salatiga. Wacana Akademika Volume 1 No 2 Tahun 2017.

Shoimin, A. 2014. 68 Model Pembelajaran Inovatif dalam Kurikulum 2013. Yogyakarta: Ar-Ruzz Media. Suprihatiningrum, J. 2017. Strategi Pembelajaran . Jogjakarta : ArRuzz Media.

Susanto, Ahmad. 2013. Teori Belajar dan Pembelajaran di Sekolah Dasar. Jakarta: Kencana Prenada Media Group. 